\title{
Propaganda Feminisme dan Perubahan Sosial
}

\author{
Muthiah Umar
}

\section{ABSTRACT}

\begin{abstract}
Feminist movement was born as reaction toward discrimination, unfairness, and oppression toward women in social system. In principle, the movement viewed that the root cause of such problem could be traced back to state development policy eternalized by patriarchal family system and religious doctrines. Upon its socializations, feminist movement utilizes propaganda technique to construct their message in order to provide different communication effects. For over the years, despite pro-cons over feminism, the feminist movement has significantly changed the world's social system as appear on some levels such as patterns of behavior and human interactions. A solution focused on ethical dimension of Human Development which being framed and reinterpreted in the manner of theological beliefs was needed to increase the result of feminist movement.
\end{abstract}

Kata kunci: feminisme, propaganda, human development, perubahan sosial

\section{Pendahuluan}

Pada tahun 1975, PBB telah mencanangkan Tahun Internasional Wanita yang kemudian dilanjutkan dengan Dasawarsa Wanita 1976-1985. Hampir seluruh negara-negara di dunia terpengaruh untuk memberikan perhatian terhadap permasalahnpermasalahan yang dihadapi oleh kaum wanita. Hal ini tidak terlepas dan kebangkitan feminisme di negara-negara Barat pada tahun-tahun 1960-an. Indonesia sendiri tidak ketinggalan dari gerakan global ini. Dan untuk pertama kalinya, GBHN tahun 1978 telah memuat amanat untuk meningkatkan peranan wanita, yang kemudian ditindaklanjuti dengan berdirinya Lembaga Menteri Muda Urusan Peranan Wanita pada tahun 1979.

Pemerintah Indonesia bahkan telah meratifikasi Konvensi Penghapusan segala Bentuk Diskriminasi terhadap Wanita (Convention on the
Elemination of All Forms of Discrimination Against Women) dengan Undang-Undang No.7 tahun 1984, hal ini oleh Jang Aisjah Muttalib dianggap telah memberi sumbangan yang cukup berarti dalam membuka jalan menuju perubahan yang bersifat struktural. ${ }^{1}$

Di kalangan infrastruktur, gerakan emansipasi wanita mulai diteriakkan oleh organisasi-organisasi wanita, dan menjadi lebih kuat dengan terbentuknya federasi berbagai organisasi wanita sebagai hasil Kongres Perempoean Indonesia I di Yogyakarta, pada Desember 1928. Ini dikenang sebagai akar sejarah yang kuat bagi gerakan pemberdayaan perempuan. Setelah reformasi sosial politik pada pertengahan Mei 1998, gerakan pemberdayaan perempuan bertambah kencang seiring menjamurnya berbagai Lembaga Swadaya Masyarakat yang membawa misi pemberdayaan perempuan, di mana pemberdayaan perempuan 
kemudian menjadi program yang didesakkan penerapannya ke dalam sistem sosial, sebagai salah satu upaya yang secara jelas akan memengaruhi kebijakan sosial.

Feminisme menjadi fenomena yang lebih berkembang pada dua dekade terakhir. Feminisme memberikan stimulan dan dorongan bagi munculnya gerakan perempuan sebagai gerakan sosial, di mana gerakan seperti ini tidak muncul tiba-tiba, melainkan merupakan perkembangan di mana ada rasa cemas dan keinginan-keinginan individu yang menghendaki perubahan dan yang kemudian bergabung dalam suatu tindakan bersama. Kecemasan yang muncul akibat kesadaran akan posisi perempuan yang rendah dalam masyarakat dan keinginan untuk memperbaiki dan mengubah keadaan tersebut.

Pada dasarnya, semua feminis berangkat dan kesadaran telah terjadinya diskriminasi dan ketidakadilan terhadap perempuan dalam berbagai bidang kehidupan. Tetapi, alasan mereka terhadap situasi ini tidak sepenuhnya sama. Mereka mendekati dan menganalisis persoalan dan masing-masing sudut pandang, sehingga strategi untuk mengatasinya juga bermacam-macam.

\section{Feminisme Liberal}

Feminisme liberal, misalnya, sejak awal telah berasumsi bahwa kaum perempuan lebih dianggap sebagai masalah bagi ekonomi modem dibandingkan kaum laki-laki. Dalam salah satu studi yang dilakukan oleh Mc Clelland tentang motivasi berprestasi, misalnya dorongan perempuan untuk otonomi dan berhasil, dilihatnya sebagai variabel penting dalam pembangunan. Tetapi kaum perempuan tidak mampu mewujudkan dorongan untuk need of achievement mereka, sehingga akan diturunkan kepada anak lelaki mereka.

Pada saat proses pembangunan dan hasilnya diasumsikan sebagai kemudahan bagi kaum perempuan, di mana industrialisasi dianggap akan menekan kesenjangan yang terjadi akibat perbedaan kemampuan biologis laki-laki dan perempuan, serta program KB dinyatakan sebagai upaya untuk membebaskan perempuan dari kewajiban reproduksi yang tidak ada hentinya, sehingga dengan kebebasan dan mobilitasnya perempuan dapat meningkatkan nilai-nilai dan harapannya, maka feminis liberal muncul untuk memberikan reaksi terhadap kebijakan pembangunan liberal tersebut.

Dengan menggunakan analisis dan sudut pandangnya, feminis liberalis menyatakan bahwa ketertinggalan perempuan dalam proses pembangunan adalah karena faktor internal perempuan itu sendiri. Perempuan tidak berani untuk bersaing, dan ini terkait dengan kebudayaan yang dianut masyarakatnya. Karena itu, menurut feminis liberalis, sesungguhnya pembangunan dan modernisasi, teknologi, maupun sistem ekonomi memberikan peluang yang sama luasnya bagi siapa saja, tetapi hanya yang modern, kreatif, rasional dan efisienlah yang akan mampu memanfaatkan kesempatan itu. ${ }^{2}$

Mereka juga mengajukan solusi untuk menghentikan proses marjinalisasi kaum perempuan dengan memperjuangkan perubahan hukum dan peraturan, sehingga perempuan dapat memiliki akses dan kontrol yang sama pada pekerjaan dan imbalan ekonomi.

\section{Feminisme Marxis}

Menurut feminisme Marxis, pertanyaan tentang perempuan harus diletakkan sebagai bagian dan kritik terhadap kapitalisme, terutama pada sistem mode produksi. Maka, bila berbicara tentang posisi kaum perempuan, para feminis Marxis berasumsi bahwa rendahnya posisi kaum perempuan adalah akibat dan struktur produksi. Mereka berpijak pada analisis Engels bahwa melalui proses sejarah kaum perempuan berubah dan anggota masyarakat yang bebas dan equal menjadi subordinat dan istri yang bergantung. Pertumbuhan kepemilikan pribadi dengan keluarga sebagai lembaga yang memerasnya dan melanggengkannya adalah akar persoalan perempuan. Karena itu feminis Marxis percaya bahwa status perempuan akan berubah hanya melalui revolusi sosial dan penghapusan pekerjaan domestik, sementara teknologi dan idustrialisasi juga dipandang akan dapat membebaskan perempuan. $^{3}$ 


\section{Feminisme Radikal}

Di dalam beberapa perspektif feminisme radikal, digambarkan bahwa wanita ditindas oleh sistem-sistem patriarkis, ini adalah penindasanpenindasan yang mendasar yang secara signifikan berhubungan dengan penindasan berganda seperti rasisme, eksploitasi jasmaniah, heteroseksisme dan kelas-isme. Menurut mereka, agar wanita terbebas dan penindasan, perlu mengubah masyarakat yang berstruktur patriarkis.

Unsur pokok patriarki dalam analisis feminis radikal adalah adanya kontrol terhadap wanita melalui kekerasan. Keluarga inti sebagai institusi masyarakat yang mewajibkan heteroseksualitas dituduh sebagai benteng pertahanan kekuasaan patriarkis. Karena itu, mereka menawarkan homoseksulitas. ${ }^{4}$ Dengan membuat kebebasan pilihan homoseksualitas itu, mereka menganggap akan ada kemungkinan-kemungkinan untuk melenyapkan penindasan individual dan struktural.

\section{Feminisme Sosialis}

Bagi feminisme sosialis, patriarki dan kelas adalah sumber penindasan. Juliet Mitchell sebagai peletak dasar feminisme sosialis, dengan jelas menyejajarkan konsep patriarki dan kapitalisme. Menurutnya, persamaan akses, revolusi ekonomi, atau kontrol reproduksi, tidak akan dapat menghapuskan penindasan terhadap wanita. Kedua hal itulah — patriarki dan kapitalismeyang harus dilenyapkan untuk membebaskan wanita.

Feminis sosialis mempunyai tujuan, yaitu: pertama, menghilangkan institusi keluarga sehingga masyarakat egaliter dapat tercipta; kedua, mengubah sistem nilai dan agama yang menurut paradigma sosial-konflik adalah sebuah superstruktural yang dapat diubah.

Pendekatan feminisme sosialis ini, dimungkinkan sebagai bertemunya aliran feminisme Marxis dengan feminisme radikal dan pemikiran psikoanalisis yang lebih kuat.

\section{Feminisme Kultural}

Fokus feminisme kultural adalah pandangan bahwa feminitas merupakan bentuk perilaku manusia yang paling diperlukan. Untuk melihat pandangan ideal melalui maskulinitas, dan cap-cap yang diberikan kepada feminitas oleh dunia patriarkis, kaum feminis kultural mendefinisikan kembali feminis dalam suatu kerangka positif. Teori yang digunakan biasanya adalah teori utopia.

Jessic Bernard dalam Ollenburger (1996:31), mendefinisikan eksistensi wanita sebagai suatu realitas terpisah dan unik, yang memberikan (1) suatu sistem terintegrasi yang sangat penting bagi pertahanan keluarga (2) cinta dan atau etos tugas; dan (3) suatu loncatan budaya melalui kesadaran yang nyata melalui perilaku verbal/non verbal atau melalui teknologi-teknologi sendiri.

\section{Feminisme Pascastrukturalis}

Kaum feminis pascastruktural memfokuskan pada cara-cara pemecahan masalah secara individual, seperti diskriminasi ekonomi. Tidak ada jalan lain bagi wanita bila ingin keluar dan subordinasi sistem patriarkis adalah dengan mengatasi kekuatan-kekuatan keadaan sekitarnya. De Beauvoir dalam Ollenburger ${ }^{5}$ menganjurkan tiga strategi: pertama, wanita harus bekerja, meskipun bekerja dalam sistem kapitalis bersifat eksploitasi dan menindas. Hanya melalui pekerjaan wanita akan mampu mengontrol nasib mereka sendiri. Kedua, wanita perlu menjadi intelektual; sebab aktivitas intelektual meliputi berpikir, mencari, dan mendefinisikan, sebagai lawan dan dipikirkan, dicarikan dan didefinisikan. Ketiga, wanita harus berusaha untuk menjadi sosialis yang mentransformasikan masyarakat, yang akan mcmbantu menanggapi konflik-konflik subjek/ objek dan diri sendiri/orang lain.

\section{Propaganda dan Media Massa dalam Gerakan Feminisme}

Diakui oleh berbagai kalangan bahwa munculnya permasalahan dalam pandangan para feminis, bukan semata-mata kesalahan berbagai model teori yang berkaitan dengannya. Keterbelakangan perempuan adalah akibat dan sikap kebodohan dan sikap irasional karena kepercayaan sikap tradisional mereka. ${ }^{6}$ 
Kecenderungan lain yang muncul pada gerakan ini adalah menyerap pengaruh wacana feminis tanpa memahamkan maknanya, sehingga seringkali menimbulkan sikap reaksioner. Akumulasi reaksioner ini kemudian muncul dalam wujud sosialisasi ideologi yang membabi buta dan keluar dari konteksnya. Pengaruh-pengaruh pengalaman dan interest setiap tokoh dapat menyebabkan melebarnya duduk persoalan dan solusi pemecahannya.

Kesalahan interpretasi ini pada kenyataannya dikekalkan dengan bantuan proses komunikasi dan media massa. Ideologi feminis yang dikemas dalam bentuk propaganda, baik secara halus maupun radikal, dengan mengandalkan kekuatan media massa dan industri hiburan yang secara sistematis mampu mengubah gaya hidup setiap orang yang tidak mempunyai resistensi terhadap bujukan dan pengaruh.

Menurut konteks proses komunikasi massa, feminisme telah menggunakan teknik propaganda untuk menyebarluaskan ideologinya. Jenis propaganda ideologi atau doktrin mi, menjadi teknik bagi penyebarluasan ideologi yang biasa ditetapkan oleh suatu pemerinah, organisasi, atau lembaga, agar komunikan yang menjadi objeknya menerima dan kemudian bertingkah laku, berpandangan, bersikap dan berpendapat seperti apa yang dipolakan oleh pencetusnya dan komunikatornya.

Propaganda dewasa ini sangatlah komplit. Propaganda mengelilingi kita seperti halnya udara yang kita hirup. Propaganda ada di mana-mana. Semuanya bersifat membujuk dan memengaruhi. Hidup pada masa kini adalah untuk diterpa dengan benih-benih bujukan yang seringkali kita hadapi tanpa kesadaran dan kesengajaan, yang menyebar di sekeliling kita dan seringkali tertanam dalam diri kita.

Menurut Qualter dalam Santoso, propaganda adalah suatu usaha yang dilakukan secara sengaja oleh beberapa individu atau kelompok untuk membentuk, mengawasi atau mengubah sikap dan kelompok-kelompok lain dengan menggunakan media komunikasi dengan tujuan bahwa dalam setiap siatuasi yang tersedia, reaksi dan mereka yang dipengaruhi akan seperti yang diinginkan oleh si propagandis ${ }^{7}$ dengan kata lain, komunikasi secara sengaja digunakan untuk memodifikasikan sikap sasarannya. Sedangkan dalam ideologi tersebut telah termuat sejumlah nilai dan kebijakankebijakan tertentu.

Proses penghasutan yang dilakukan oleh para feminis melalui media massa memang cukup efektif. Menurut Ratna Megawangi, Efek yang dihasilkannya seperti "stalagmite effects", di mana aspek kognitif manusia akan mendeposit sedikit demi sedikit pesan-pesan yang disampaikan oleh media. 'Efek kumulatif mi terutama akan besar pengaruhnya terhadap pembentukan persepsi nilai-nilai generasi muda terhadap lembaga perkawinan. Bila kampanye anti keluarga terus menerus didengungkan, maka hanya dalam satu generasi pandangan masyarakat tentang kumpul kebo, misalnya, pasti akan berubah. Amerika dan Eropa pada umumnya adalah contoh dan masalah ini. $^{8}$

Doktrin feminisme diarahkan pada upaya untuk mengubah sikap, tidak saja sikap individual tetapi lebih jauh yang diharapkan berubah oleh doktrin mi adalah sikap sosial. Sikap sosial secara sengaja dan sistematis terbentuk oleh situasi perangsangan yang bersifat sosial. Apa yang disebut sebagai sosialisasi dalam masyarakat tidak lain adalah pembentukan sikap sosial pada setiap individu. Sikap sosial pula yang menyebabkan terjadinya tingkah laku yang khas terhadap objek sosial, karena itu sikap sosial turut menjadi faktor penggerak intern di dalam pribadi orang yang mendorongnya bertingkah laku tertentu.

Salah satu majalah menurunkan laporan tentang maraknya propaganda feminisme yang memuat gagasan, simbol, dan slogan seperti hakhak wanita, pembebasan kaum wanita dan gencar menghantam institusi keluarga sebagai basis kekuatan masyarakat.

Dr. Syarifah dalam Ummu Hani menyatakan bahwa masyarakat telah menjadikan perempuan sebagai alat kampanye barang produksi agar laku dalam pemasarannya. Tragisnya, posisi seperti itu malahan dibanggakan sebagai lambang kebebasan dan kemodernan. ${ }^{9}$

Seorang feminis terkenal di Indonesia dan 
merupakan salah seorang pendiri Yayasan Kalyanamitra wadah feminis Indonesia yang paling berpengaruh, telah beropini dalam sebuah tulisan hasil wawancara di Majalah Tiara, dia mengatakan lebih setuju jika lembaga perkawinan dilenyapkan sama sekali. Menurutnya, open marriage jauh lebih sehat daripada poligami. "Lebih bagus kita kenalan, jatuh cinta, hidup bersama, membina suatu rumah tangga sampai kita tidak cocok lagi. Mau sampai berapa tahun pun kalau kita nggak cocok, kita cari lagi partner lain yang cocok." 10

Berbagai sampel lain dari kesalahkaprahan kaum feminis dalam mengejawantahkan prinsip kebebasan, egalitis, dan semacamnya yang mereka usung dalam kehidupan sosial, menjadi sesuatu fenomena yang mudah didapatkan dalam sistem sosial masa kini dan menjadi sebuah hegemoni, persis seperti ketika pada awalnya diskriminasi dan ketidakadilan terhadap perempuan juga telah menjadi sebuah hegemoni.

Beberapa konferensi dunia yang didedikasikan untuk perempuan, seperti Konferensi Kairo dan Beijing, dalam analisa beberapa pengamat bahkan disinyalir merupakan sebuah konspirasi tingkat tinggi dari para feminis Barat dan pemerintah negara-negara Barat untuk memaksakan diberlakukannya isu-isu tentang "pemberdayaan" perempuan. Isu kapitalisme, permisivisme dan model-model gaya hidup Barat lainnya yang bahkan menunjukkan jahiliyyah gaya baru, didorong untuk menjadi model gaya hidup global.

Dr. Majid L. Katme, seorang cendekiawan Muslim Inggris, misalnya, menemukan bahwa sejumlah kalimat dalam dokumen konferensi Beijing secara perlahan dan pasti berniat merusak lembaga perkawinan serta mengurangi hak-hak wanita yang sebenamya telah dijamin dalam Islam.

Mengenai gerakan penghancuran institusi keluarga, kaum feminis, menurut Dekan Fakultas Ushuluddin Universitas Al Azhar dalam Ummu Hani, sedikitnya menggunakan lima cara, yakni:

(1) Menghancurkan sistem perkawinan dan struktur keluarga dalam Islam serta menyebarkan struktur lain dalam hubungan laki-laki perempuan di luar pernikahan (struktur keluarga yang tidak dibentuk dengan ikatan pernikahan).

(2) Mendorong wanita Muslimah agar bersolek, memamerkan perhiasan dan daya tariknya di bawah slogan "kebebasan wanita".

(3) Mendorong wanita untuk melakukan pergaulan sebebas-bebasnya yang dilukiskan sebagai membudayakan wanita dan modernisasi serta membangun hubungan harmonis antara laki-laki dan perempuan.

(4) Menghancurkan hak kepemimpinan dalam Islam dan mendorong wanita untuk melakukan pemberontakan terhadap sistem keluarga.

(5) Mendorong pemerintah di dunia Islam untuk mengganti perundang-undangan Islam tentang keluarga dengan perundangundangan bathil. ${ }^{11}$

\section{Perubahan Sosial sebagai Dampak Gerakan Feminisme}

Wilbert Moore dalam Lauer mendefinisikan perubahan sosial sebagai "perubahan penting dan struktur sosial." Yang dimaksud dengan struktur sosial adalah "pola-pola perilaku dan interaksi sosial. Moore memasukkan ke dalam definisi perubahan sosial bcrbagai ekspresi mengenai struktur seperti norma, nilai, dan fenomena kultural. ${ }^{12}$

Ada yang berpendapat bahwa perubahan tidak terjadi, atau sekurang-kurangnya tidak ada perubahan penting jika institusi itu sendiri tidak berubah. Ada pula yang berpendapat bahwa perubahan sikap pun mencerminkan perubahan penting dalam kehidupan sosial.

Dapat dibuktikan bahwa gerakan kaum feminisme telah mendorong struktur sosial untuk berubah, dalam hal ini adalah pola-pola perilaku dan interaksi sosial dalam berbagai tingkatannya, baik individu, komunitas, masyarakat, kebudayaan, peradaban dan global.

Dalam konteks feminisme sebagai kepedulian terhadap nasib kaum perempuan, maka upayaupaya yang dilakukan oleh para aktivis dan kaum perempuan itu sendiri, telah menggeser posisi perempuan dalam struktur sosial pada posisi yang 
lebih baik. Perempuan telah menjadi variabel sosial yang diperhitungkan dan dilibatkan dalam proses sosial.

Sementara itu, dalam konteks gerakan feminisme radikal, dengan asumsi bahwa keluarga adalah salah satu bentuk penindasan terhadap kebebasan individu, maka pola-pola interaksi sosial dan tata pergaulan menjadi bergeser.

Para perempuan berbondong-bondong mengejar karier di sektor publik dalam rangka mencari kesetaraan ekonomi dan eksistensi dini dalam lingkungan sosialnya, sehingga peran-peran domestik mereka terlalaikan atau dialihkan kepada tenaga kerja yang mereka upah untuk menggantikan tugas mereka. Anak-anak menjadi terlantar dan para suami lebih punya alasan untuk berselingkuh. Praktek-praktek hidup bersama pasangan samen leven, free sex, homoseksual, bayi-bayi yang dilahirkan oleh para wanita yang tidak menikah dan laju pertumbuhan orang tua tunggal, menjadi fenomena sosial dewasa ini.

Bagaimanapun, berbagai penelitian telah memberikan gambaran yang signifikan atas pengaruh gerakan feminisme ini terhadap perubahan sosial.

\section{Penolakan terhadap Propaganda Feminisme}

Marry Ann Mason seorang ahli hukum di Amerika yang banyak menangani kasus-kasus perceraian di AS, menyatakan bahwa sebelumnya ia adalah seorang feminis yang sangat mendambakan kesetaraan gender. Namun ia melihat betapa banyak wanita yang justru menderita karena adanya konsep equal treatment. Apa yang tertera dalam ERA bahwa tidak ada masalah bagi wanita untuk dapat melakukan apa saja seperti apa yang dilakukan pria dengan term yang sama, ternyata telah menggiring wanita dalam konflik, yaitu antara karier dan peran keibuannya. Akhirnya ia mengatakan bahwa perlakuan sama antara pria dan wanita tidak dapat diterapkan, dan tentunya kesetaraan gender adalah mustahil tercipta.

Menurutnya, Sekarang saya mengerti mengapa

kebanyakan feminis pada 1920 dan '30-an sangat tidak setuju dengan ERA, seperti Jane Addams dan Florence Howe. Mereka dapat mengerti kebenaran fundamental tentang kehilangan yang diderita oleh wanita modern, bahwa wanita memerlukan perlakuan khusus dalam perannya sebagai ibu. Kesetaraan adalah pedang bermata dua yang dapat mencelakakan perempuan dan juga menolongnya. Kesetaraan hanya dapat menjadi sebuah strategi layak hanya dalam situasi terbatas dimana para wanita ada dalam kondisi yang sama dengan pria. Karenanya ini dapat menjadi strategi bagi perempuan muda atau para perempuan yang tidak mau punya anak dan ingin berkompetisi dengan pria. Wanita dengan anak selalu mendapatkan bagian yang tajam dari pedang. ${ }^{13}$

Disintegrasi keluarga yang akhir-akhir mi menjadi sangat banyak muncul, disinyalir oleh Alberto Tita dalam Anthony Giddens sebagai kecenderungan demografis yang paling merugikan darn generasi manusia saat mi. Menurut Tita,"hal itu juga yang merupakan mesin yang menggerakkan masalah-masalah sosial kita yang paling urgen, dan kejahatan sampai kehamilan pranikah, ke penyimpangan seksual hingga kekerasan domestik terhadap wanita ${ }^{14}$.

Giddens menganalisis bahaya disintegasi keluarga ini dengan menyarankan untuk menegaskan kembali kesakralan perkawinan. Perkawinan adalah medan pelatihan emosional yang penting bagi kaum pria yang senang keluyuran, yang mengikat mereka pada kewajiban dan tanggung jawab yang jika tanpa perkawinan akan mereka abaikan.

Menurut Soekanto, keluarga adalah salah satu basic institutions yang terpenting, yang dianggap sebagai lembaga kemasyarakatan yang sangat penting untuk memelihara dan mempertahankan tata tertib dalam masyarakat ${ }^{15}$.

Pada saat sekumpulan norma dikatakan telah "melembaga" (institutionalized), maka ada beberapa dimensi norma tersebut yang menjadi ciri pentingnya, yaitu: (1) diketahui (2) difahami atau dimengerti (3) ditaati (4) dihargai (5) diinternalisasi (1990:224). Dimensi-dimensi tersebut dapat digunakan untuk mengukur tingkat sikap dan pandangan anggota masyarakat terhadap institusi keluarga. 


\section{Beberapa Pendekatan Teoretis}

Untuk menganalisis permasalahan ini, maka digunakan beberapa pendekatan sebagai upaya untuk menguraikan, menjelaskan, dan membuktikan bermacam-macam fenomena feminisme, di antaranya adalah paradigma feminisme, paradigma pembangunan, analisis gender dan paradigma teologi feminis.

Paradigma Feminisme merupakan kumpulan pemikiran, pendirian, dan aksi berangkat dari kesadaran, asumsi, dan kepedulian terhadap ketidakadilan, ketidaksetaraan, penindasan atau diskriminasi terhadap perempuan, serta merupakan gerakan yang berupaya untuk menghentikan segala bentuk ketidakadilan dan diskriminasi, dan dalam perkembangan selanjutnya gerakan feminisme juga memproyeksikan suatu visi masyarakat yang adil, demokratis, dan sejahtera dalam perspektif feminisme. Menurut Mansour Fakih, dalam konteks ini feminisme dapat dikategorikan sebagai teori perubahan sosial ${ }^{16}$.

Berdasarkan paradigma ini, visi masyarakat yang adil, demokratis, dan sejahtera dapat dicapai dalam konsep pembangunan yang mengharuskan untuk mempertimbangkan dimensi etik, yakni menempatkan nilai kemanusiaan. Bagi Gutierez ${ }^{17}$, pembangunan bermakna kombinasi mental dan perubahan sosial yang mampu membawa akumulasi secara permanen atas dasar produksi total secara nyata. Pendekatan humanistik ini mencoba menempatkan pembangunan dalam konteks yang lebih luas: visi sejarah yang menganggap manusia mampu mengontrol nasib sendiri, ini yang akan membawa perubahan perspektif $^{18}$. Sedangkan menurut Budiman, pembangunan terdiri dan dua unsur pokok, yang pertama materi sebagai modal yang akan dikembangkan, dan kedua adalah manusia sebagai pengambil inisiatif dan sumber daya pembangun. Tetapi, bagaimanapun, pada akhirnya pembangunan ini harus ditujukan pada pembangunan manusia. Manusia yang dibangun adalah manusia kreatif. Untuk menjadi manusia kreatif diperlukan kondisi yang bahagia, merasa aman dan bebas dan rasa takut ${ }^{19}$ (Budiman, Arief, 2000).
Dalam ilmu-ilmu sosial, analisis gender dimanfaatkan untuk melihat relasi laki-laki dan perempuan dalam berbagai masyarakat yang berbeda. Gender sendiri terbentuk melalui proses yang panjang dan disebabkan oleh berbagai faktor. Misalnya dibentuk, disosialisasikan, diperkuat, dan dikonstruksikan secara sosial dan kultural, melalui negara, keluarga, bahkan juga ajaran agama.

Gender pada kenyataannya telah menggiring dan melahirkan sikap dan praktik yang mendiskriminasikan perempuan. Sikap dan praktik diskriminatif ini menyiratkan relasi yang bersifat politis, yaitu relasi kekuasaan antara laki-laki dan perempuan. Menurut Zakiyuddin, relasi ini harus dipahami dalam arti yang luas, yaitu sebagai relasi dominasi dan subordinasi. Dan perempuan dalam relasi seperti itu cenderung berada pada posisi subordinasi ${ }^{20}$.

Karena itu, gender akhirnya berkaitan erat dengan proses keyakinan bagaimana seharusnya laki-laki dan perempuan diharapkan untuk berpikir dan bertindak sesuai dengan ketentuan sosial dan budaya tempat mereka berada. Salah satu faktor penentu keyakinan berpikir dan bertindak itu ada pada doktrin teologis agama. Hanya saja seringkali agama ditafsirkan oleh para pengikutnya sedemikian rupa sehingga dapat melegitimasi struktur sosial untuk mendiskriminasikan perempuan.

Karena itulah, muncul paradigma teologi feminis yang berusaha untuk merekonstruksi dan mereinterpretasi doktrin-doktrin agama yang dianggap memarjinalkan perempuan dan mengekalkan dominasi laki-laki. Wacana yang dikemukakan dalam teologi feminis mi adalah dengan merenungkan persilangan antara agama dengan kehidupan perempuan. Dalam prosesnya, teologi feminis tidak hanya ingin mengubah kenyataan-kenyataan sosial, ekonomi, politik, hukum, emosional, dan spiritual perempuan, tetapi juga untuk memperbarui tradisi agama itu sendiri. Tidak peduli seberapa kaku dan mapannya tradisi yang tampak dalam berbagai persoalan, ia harus tanggap dan berubah jika memang rekonstruksi mayoritas menghendakinya atas dasar kebenaran reinterpretasi doktrin agama. 


\section{Teologi Feminis sebagai Solusi}

Selain lembaga keluarga yang dituduh sebagai sumber kebobrokan sistem sosial, nilai-nilai, dan norma sosial serta agama pun dianggap oleh kaum feminis sebagai pengekal marjinalisasi perempuan. Dari hasil riset Riffat Hassan, menyimpulkan bahwa dari tradisi Islam, Kristen, dan Yahudi, terdapat 3 (tiga) interpretasi asumsi teologis, di atas nama suprastruktur superioritas laki-laki atas perempuan (yang mengimplikasikan ketidaksetaraan antara laki-laki dan perempuan) ditegakkan. Ketiga interpretasi asumsi itu adalah:

(1) Bahwa ciptaan Tuhan yang utama adalah lakilaki, bukan perempuan, karena perempuan diyakini telah diciptakan dan tulang rusuk lakilaki, karenanya secara ontologis bersifat derivatif dan sekunder.

(2) Bahwa perempuan - bukan laki-laki - adalah penyebab utama dan apa yang biasanya dilukiskan sebagai "kejatuhan" pengusiran manusia dari surga adn. Karena itu, semua "anak perempuan Hawwa" harus dipandang dengan rasa benci, curiga, dan jijik.

(3) Bahwa perempuan diciptakan tidak saja dari laki-laki, tapi juga untuk laki-laki, yang membuat eksistensinya semata-mata bersifat instrumental dan tidak memiliki makna yang mendasar ${ }^{21}$. Secara teoretis maupun praktis, ketiga persoalan tersebut menjadi sangat signifikan dalam sejarah gagasan-gagasan dan sikap-sikap menyangkut perempuan dalam tradisi Islam, Kristen, dan Yahudi. Karena itu, menurut Riffat, sudah saatnya bagi kita untuk mengembangkan apa yang disebut orang Barat sebagai "teologi feminis" dalam konteks Islam, dengan tujuan untuk membebaskan bukan hanya perempuan Muslim, tetapi juga laki-laki Muslim dari strukturstruktur dan undang-undang yang tidak adil, yang telah memungkinkan terjadinya relasi yang hidup antara laki-laki dan perempuan.

Ghazala Anwar, seorang Muslimah yang peduli dengan masalah ini, merumuskan seorang Muslim sebagai orang yang mencintai perdamaian. Dia merumuskan perdamaian sebagai ketiadaan kekurangan (a lack of lack $)^{22}$. Islam baginya adalah tiadanya segala bentuk keburukan, ketidakadilan, dan penindasan.

Ghazala memandang feminisme sebagai sebuah gerakan di dalam gerakan umum untuk memulihkan martabat, kebebasan, dan kesetaraan, bukan hanya di antara manusia, melainkan juga di antara seluruh makhluk yang mendiami bumi. Tidak ada konflik antara pemahaman agama dengan pemahaman feminisme. Dalam arti yang luas, dia memakai istilah 'feminisme' sebagai orang yang menjadikan kesejahteraan hidup perempuan sebagai kepedulian utama dalam kehidupannya sendiri. Feminis ini bisa perempuan, bisa juga lakilaki.

Secara teologis, perempuan dan laki-laki diciptakan semartabat. Paradigma lama yang dikemukakan Riffat Hassan sebelumnya, telah bergeser kepada paradigma baru yang melihat kaitan antara perempuan dan agama secara lebih positif. Teologi feminis merupakan teologi pembebasan dalam perspektif agama. Sebagaimana teologi pembebasan berorientasi pada refleksi-aksi demi pemerdekaan dan pembelaan terhadap kemanusiaan, demikian pula dengan teologi feminis.

Secara khusus, teologi feminis berusaha untuk menanggapi masalah yang dialami perempuan, dengan mainstream yang diperjuangkan adalah membongkar konstruksi dan reinterpretasi yang salah tentang keluarga, masyarakat, negara, dan agama dengan segala persoalan yang menyertainya.

Apabila dalam paradigma lama, kaum perempuan sebagian besar menjadi objek teologi, maka untuk dapat mengangkat gerakan feminisme ke dalam sistem yang benar, perempuan dituntut untuk menjadi subjek teologi.

\section{Penutup}

Meminjam ungkapan Ghazala Anwar bahwa dalam paradigma lama kebutuhan dan keinginan laki-laki dengan perempuan itu berbeda, sehingga terjadi praktik yang menyalahi pemenuhan hak-hak perempuan sebagaimana yang tersurat dalam $\mathrm{Al}$ Quran dalam berbagai komunitas Muslim. Disadari atau tidak oleh perempuan itu sendiri bahwa laki- 
laki telah merampas hak-hak itu dan mereka atau bahkan mereka sendiri yang telah menyerahkan hak-hak itu kepada laki-laki akibat ketidakpahaman kaum perempuan terhadap Al Quran.

Maka kemudian paradigma baru mengajak perempuan untuk mempunyai keinginan yang kuat menjadi subjek teologi, dengan kualifikasi keilmuan yang harus dikejar seperti halnya keilmuan yang telah dikuasai oleh kaum laki-laki, sehingga penafsiran kembali terhadap ayat-ayat secara filologis dan kontekstual dengan kesadaran kaum perempuan akan kebutuhan keterlibatan diri mereka dalam kegiatan semacam ini, yang pada gilirannya akan mengantarkan pada terciptanya sistem sosial yang lebih seimbang.

\section{Catatan Akhir}

1 Muttalib, Jang Aisyah, 1997. Pemberdayaan Wanita antara Harapan dan Kenyataan. Dalam E.K.M Masinambow (ed.), Koentjaraningrat dan Antropologi di Indonesia. Jakarta, Yayasan Obor Indonesia.

2 Fakih,Mansour, 2002. Runtuhnya Teori Pembangunan dan Globalisasi. Yogyakarta, Pustaka Pelajar.

Op.cit. Fakih,Mansour. Runtuhnya hlm. 158

4 Megawangi, Ratna, 2001. Membiarkan Berbeda? Sudut Pandang Baru tentang Relasi Gender. Bandung, Mizan.

5 Ollenburger, Jane C., and Moore, Helen A., 1996. Sosiologi Wanita. Jakarta, Rinekacipta.

6 Opcit. Fakih, Mansour. Runtuhnya....... hlm. 149

7 Sastropoetro, R.A.Santoso, 1991. Propaganda Salah Satu Bentuk Komunikasi Massa. Bandung: Alumni

8 Op.cit. Megawangi, Ratna. Membiarkan hlm. 140141

9 Hanni, Ummu, Rekayasa Demografis dan Globalisasi Kerusakan, Aspek Konspiratif Konferensi Kairo dan Beijing. Jakarta: Yayasan Thu Harapan.

${ }^{10}$ Lihat Majalah Tiara, edisi ke 179, terbit tanggal 23 Maret 1997.

11 Op.cit. Hanni,Ummu, Rekayasa.... Hlm. 117

${ }^{12}$ Lauer, Robert H., 2001. Perspektif tentang Perubahan Sosial. Jakarta, Rineka Cipta. Penerjemah: Alimandan,SU.

13 Op.cit. Megawangi,Ratna, Membiarkan.....hlm. 126.

${ }^{14}$ Giddens, Anthony, 2000. Jalan Ketiga: Pembaharuan
Demokrasi Sosial. Jakarta, Gramedia.

15 Soekanto, Soerjono, 1990. Sosiologi Suatu Pengantar. Jakarta: Pt. RajaGrafindo

${ }^{16}$ Op.cit., Fakih, Mansour, Runtuhnya.. . .hlm. 145.

${ }^{17}$ Gustavo Gutierez. Tokoh Teologi Pembebasan dari Amerika Latin.

18 Op.cit., Fakih, Mansour, Runtuhnya....hlm. 180

19 Budiman, Arief. 2000.

20 Baidhawy, Zakiyuddin, 1996. Wacana Teologi Feminis. Yogyakarta, Pustaka Pelajar.

21 Hassan, Riffat, 2000. Setara di Hadapan Allah. Yogyakarta: LSPPA.

22 Op.cit., Baidhawy, Zakiyuddin. Wacana hlm. 3

\section{Daftar Pustaka}

Baidhawy, Zakiyuddin. 1996. Wacana Teologi Femninis. Yogyakarta: Pustaka Pelajar.

Budiman, Arief. 2000. Teori Pembangunan Dunia Ketiga. Jakarta: Gramedia.

Combs, James B., and Dan Nimmo. 1994. Propaganda Baru. Bandung: Remaja Rosdakarya.

Fakih, Mansour. 2002. Runtuhnya Teori Pembangunan dan Globalisasi. Yogyakarta, Pustaka Pelajar.

Giddens, Anthony. 2000. Jalan Ketiga: Pembaruan Demokrasi Sosial. Jakarta: Gramedia.

Hanni, Ummu, 1996. Rekayasa Demografis dan Globalisasi Kerusakan: Aspek Konspirat Konferensi Kairo dan Be ing. Jakarta, Yayasan Ibu Harapan.

Ihromi T. 1999. Bunga Rampai Sosiologi Keluarga. Jakarta, Yayasan Obor Indonesia.

Lauer, Robert H. 2001. Perspektif tentang Perubahan Sosial. Jakarta, Rineka Cipta. Penerjemah: Alimandan,S.U.

Megawangi, Ratna. 2001. Membiarkan Berbeda? Sudut Pandang Baru tentang Relasi Gender. Bandung: Mizan. 
Mernissi, Fatimah, dan Hassan, Riffat, 2000. Setara di Hadapan Allah. Yogyakarta, LSPPA. Penerjemah: Tim LSPPA.

Muttalib, Jang Aisyah. 1997. "Pemberdayaan Wanita antara Harapan dan Kenyataan." Dalam E.K.M Masinambow (ed.), Koentjaraningrat dan Antropologi di Indonesia. Jakarta: Yayasan obor Indonesia.
Ollenburger, Jane C., and Moore, Helen A., 1996. Sosiologi Wanita. Jakarta: Rinekacipta.

Sastropoetro, R.A.Santoso, 1991. Propaganda: Salah Satu Bentuk Komunikasi Massa. Bandung: Alumni.

Soekanto, Soerjono. 1990. Sosiologi Suatu Pengantar. Jakarta: PT. Rajagrafindo. 